\title{
Efforts to Overcome Child Commercial Sexual Exploitation Victims in City Tourism Area, Manado
}

\author{
Rahmat Hidayat ${ }^{1}$ \\ Budiman Rusli ${ }^{2}$ \\ Sintaningrum ${ }^{3}$ \\ Yogi Suprayogi Sugandi ${ }^{4}$
}

\begin{abstract}
The tourism sector has a significant contribution to the economy of Manado City, North Sulawesi Province. However, on the other hand, it has a negative effect on the increase in the number of child commercial sexual exploitation victims, and aids children into becoming commercial sex workers. However, the Local Government of Manado City, North Sulawesi Province, has made efforts to cope with the child commercial sexual exploitation victims. In connection with the case, this study was designed to analyze the causes of the ineffectiveness of the Local Government efforts in tackling children commercial sexual exploitation victims. The study was conducted in tourism area of Manado City, North Sulawesi Province. The informants involved in this study were divided into two types: experts and non-experts. The informants were determined by using the Opportunistic Sampling, and the sampling is using Snowball Sampling. The results of the study showed that the development of tourism sector has a negative effect on the children in the communities. Efforts made to cope with the child commercial sexual exploitation victims by the local government and relevant parties have proved abortive, due to the limited allocation of budgets and skilled, quality human resources, the lack of harmonious understanding between police with judges and public prosecutors as law apparatus, supervision, protection of victims in solving the cases of child commercial sexual exploitation victims, the implementation of the action committee's duties and responsibility have been of no effect, the number of obstacles facing them.
\end{abstract}

\section{Keywords:}

efforts to tackle; child commercial sexual exploitation victims; tourism area; public policy implementation.

\section{Introduction}

The selection of the topic is set by the idea that Child Commercial Sexual Exploitation (CCSE) issue is the subject of a study, that has been in a particular trend in the public policies. The indication of the phenomenon is most prevalently found in Indonesia, especially tourism, industrial, and border areas. However, on the one hand, the issue is hard to indicate, as it is generally done behind closed doors in orderly, and undiscovered transactions.

In addition, the commercial sexual exploitation of children is contrary to the human rights. Therefore, requires serious thought and attention of the governments, both international and local. The commercial sexual exploitation of children has a high negative impact on the

\footnotetext{
${ }^{1}$ Public Administration, Fisip, Padjadjaran University, Bandung, Indonesia. Email: rahmah.hidayat74@yahoo.com

2 Public Administration, Fisip, Padjadjaran University, Bandung, Indonesia. Email: budiman9560@gmail.com

${ }^{3}$ Public Administration, Fisip, Padjadjaran University, Bandung, Indonesia. Email: sintaher@yahoo.com

${ }^{4}$ Public Administration, Fisip, Padjadjaran University, Bandung, Indonesia. Email: y.suprayogi16@gmail.com
} 
survival and future of the victimized children. The victimized children are vulnerable to ridicule, repeated exploitation, fraud, and marginalization. As a result, the victims cannot enjoy rights to life, such as rights to a proper education, self-actualization, participation and compliance with other basic needs like health, and reasonably life as other children.

This study was conducted in Manado City, North Sulawesi Province, in consideration that the city is one of tourist cities in Indonesia, and sensitive region as a receiver and sender of child trafficking, for the purpose of commercial sexual exploitation, particularly some areas in Indonesia, such as Papua, Maluku, Kalimantan, Batam, and Jakarta, as well as abroad, such as Malaysia, Hongkong, Taiwan, Singapore, and South Korea. Initially, they were recruited as domestic workers, and shopkeepers; however, finally, the victims were found working in entertainment locations as singers and song guides in karaoke (Nuraeny, 2011).

Manado City has had such legal instruments to protect children, as Mayor Decree Number 51 Year 2009, on the Establishment of P2TP2A Board, Manado City, Mayoral Decree Number 28 Year 2010, on the Establishment of the Action Committee for the Elimination of Forms of Worst Child Labor in Manado City, Mayor Decree Number 29 Year 2010, on the Establishment of the Secretariat of the Action Committee for the Elimination of the Forms of Worst Child Labor in Manado City. However, the legal instruments have no sufficient capacities to eradicate cases of child commercial sexual exploitation in Manado City, North Sulawesi Province. Local Government of North Sulawesi Province has organized the socialization of Child Protection Model Development in Manado, North Sulawesi; however, the program has not been effective, therefore, it's not the right solution in eliminating cases of child sexual abuse. The child commercial sexual exploitation victims indicate significant increase from year to year; i.e., in 2013 are 34 cases, in 2014 are 32, and in 2015 to 109 cases, and in 2016 to 131 cases of child commercial sexual exploitation victims (P2TP2A, North Sulawesi, July 8, 2017).

Based on those problems, this study was designed to analyze the causes of ineffective efforts by the Local Government of Manado City together with relevant parties, in tackling the child commercial sexual exploitation victims in tourism area of Manado City, North Sulawesi Province.

\section{Concept of Child Commercial Sexual Exploitation}

Conceptually, the child commercial sexual exploitation is an act of offering services, either directly or directly, from a daughter by a pimp/procurer to perform sexual acts for money or other compensations to a person or anyone (Suyanto, 2010 \& Child Wise Tourism Report, 2007).

\section{Confession of Child Commercial Sexual Exploitation Victims}

Rika Mindrayani (2004) in Surjono \& Ahyar (2009), argues that the child commercial sexual exploitation victims can be tackled in various ways as follows:

a. Multimedia-based socialization and counseling, in order to increase public understanding and awareness of the impact of CCSE.

b. Integrate knowledge of CCSE issues into the school curriculum, both formal and non-formal.

c. Improve understanding, awareness, and concern of all components in communities, government staff, and stakeholders.

d. Mobilize communities to establish and improve the system monitoring in every case of CSEC in the regions.

The following notion confirms the essence of tackling is, essentially, in the empowerment of communities, since the communities have a direct and first awareness of any case of 
child commercial sexual exploitation. When they realized early indication of the case, the community can make initial anticipation, before the casualties, contact authorities, and control over the actions of communities with regard to the commercial sexual exploitation making children into victims (Surjono \& Ahyar, 2009).

\section{Public Policy Implementation}

Policy implementation is basically a means of achieving policy goals. To implement the public policies, two alternatives are presented: direct implementation in the form of programs and formulation (Dwijowiyoto, 2003).

Hogwood and Gunn (1991) asserted the success of public policy implementation, basically, requires various criteria such as:

a. The existence of a guarantee that the external conditions encountered by organizations/ agencies will not cause important problems.

b. Availability of adequate resources including time.

c. Integration of required resources, both human and natural resources.

d. The existence of reliable causality.

e. How high is the developed causality?

f. How high the dependence of causality?

g. Level of understanding and agreement on the goals to be achieved.

h. Tasks are detailed and grouped into the appropriate space.

i. Perfect communication and coordination.

\section{Methods}

The method used in this study, is a Case Study set by the number of cases of child commercial sexual exploitation victims, which is not yet revealed, particularly in the Tourism Area of North Sulawesi Province. The case of child commercial sexual exploitation victims in Indonesia is in general, an iceberg phenomenon; so, it is the main ingredient to be appointed as part of the efforts to uncover, formulate appropriate approaches to tackle the child commercial sexual exploitation victims - local, national, or international. This study was designed in the type or form of analytical qualitative descriptive, which seeks to analyze, disclose, and explain problems facing children who are the child commercial sexual exploitation victims to the public; thus, it is expected to arouse awareness of concerned and responsible parties, to use any such of data and information in an effort to take steps right. The public also needs to be awakened by the awareness to grow and develop; children are given the opportunity to play, learn, interact naturally with their friends and express their potential. Thus adults, individuals and groups must provide optimal space for these children. This Descriptive Approach is used on the bases that the condition of children who are victims of Commercial Sexual Exploitation is indeed should be expressed as it is to the surface, not to blame anyone even if there is a responsible party, but what is needed is to generate awareness from the responsible and concerned parties.

The study of descriptive type in relation to the child commercial sexual exploitation in the tourism area of Manado City, North Sulawesi Province, is fit the concepts and school of post-positivist thoughts placing more emphasis on interpretive explanation and interpretation of relevant social symptoms (DeLeon \& Martell, 1998).

\section{Location of Research and Informant}

The location of the research is the Tourism Area of Manado City. Informants in the study are the main source of data, and they are divided into two types: experts and the nonexperts. The experts are the relevant parties that can provide information on data consisting of the informants; they are Resort Police of Manado, Child Protection Organizational Activist, social workers, medical staff, HIV/ AIDS activist, residents and local government apparatus, community leaders, religious 
figures, tourist industrial managers, pimps/ procurers. While non-expert informants are victims of the commercial sexual exploitation.

The samples of informants were determined by using Opportunistic Sampling, where the researcher utilizes incidental meetings, during visits to the location in the light of children group as victims of sexual exploitation, are hard to find and visit.

Sampling was also made by using Snowball Sampling, by which the selection of informants was started by one participant. The participants whose data have been obtained are consulted to involve other people or their friends, who may be interested or willing to participate.

\section{Data Collection Technique}

\section{Observation}

Researchers conduct unstructured observations that must be done anytime, and can be done at a certain time and place, giving the conditions of the victims is very difficult to find and visit. This is according to Suharto (1997) caused by internal and structural factors, such as: the victim's own rejection, the manipulation of the perpetrator, the family experiencing the case assume that sexual violence against children is an embarrassment and disgraceful, if expressed before the public.

\section{Mixed Observations}

In this case, the researcher stays at the research location for a certain time, lives and participates in routine activities at the research site. The involvement of the researchers in daily activities undertaken by research informants led to the creation of rapport, which is an important prerequisite in this study. Researchers will not get valid information if no mutual trust is established. Relationships do not have to be profound; the most important is the free flow and frankness in the information communication that goes with the research informant, without suspicion and efforts to close each other. Knowing each other well is woven, and most important is to accept the researcher as part of his life, so there is no longer the gap between the researcher and the research informants.

\section{In-Depth Interview}

In this case, the researchers used two interview techniques namely, structured interview and unstructured interview. Structured interview carried out to the informant expert, in this case, the Resort Police of Manado, Child Protection Organizational Activist, social workers, medical staff, HIV/ AIDS activist, residents and local government apparatus, community leaders, religious figures, tourist industrial managers, pimps/ procurers.

Unstructured interview conducted by the ordinary informants; i.e., child commercial sexual exploitation victims, pimps/procurers, and local residents, meaning that the research informants did not feel reluctant in answering questions. There is a guarantee that every informant does not know each other's answers to the questions asked; hence, the researcher is not hampered in obtaining the required information. To keep a private secret, all the names mentioned are pseudonyms. In the interview also revealed the identity of informants, family background, and association in the school, as well as the surrounding social environment of the community.

\section{Focus Group Discussion}

Upon the completion of the pre-field and field phases, the researcher saw the need to conduct focus groups or Focus Group Discussion (FGD) for more focus, and dig deeper into the understanding of the necessary victims; so that their rights can be met, as well as the response to the victims of the commercial sexual exploitation of children can be achieved.

Focus group discussion in this study was followed by research informants, in this case, 
the victims of commercial sexual exploitation of children, the reason being that the informants involved had different characteristics in the openness and closure of the answers, which were seen during the in-depth interviews. Given this discussion, it is expected that there will be openness and clarity of answers to the problems, at the time of in-depth interviews of closed informants. For informants who have been open in the discussion, it is expected to appear honestly on the answers given. To follow the focus group discussion requires an early understanding of supporting data related to the research.

\section{Data Analysis Technique}

Data analysis was done with three steps namely data processing, reduction, presentation, and conclusions/generalizations based on case findings (Cresswell, 2013). In addition, the researcher will also use Triangulation analysis that is an analysis of the situation of social, economic, cultural informants on check and recheck scale from various sources, review the enforcement of rules and laws applicable to the region.

\section{Result and Discussion}

\section{Situation and Condition of Child Commercial Sexual Exploitation in Tourism Area of Manado City}

Before discussing the efforts undertaken by Manado City Government of North Sulawesi Province in tackling various forms of commercial sexual exploitation of children in Manado City, North Sulawesi Province, the author will explore the situation and life condition of the child commercial exploitation victim in the tourism environment, as obtained by the explanation from the interviewed results as follows:

Interviews with one of the female pimps, 17 years old, called Ver are as follows:

"Initially, she was only offered jobs that accompany customers in the cafe for a drink and enticed by a large amount of money. Ver accepts the offer because she could buy an expensive phone like any other sex worker who came before her. Ver who do not understand with the work affirmed, now start to dissolve and like the work. Ver then thought to ask their friends as performed on her first." (Interview Results on October 3, 2015).

The same case occurs in Mawar, as a child commercial sex worker, who admits that she and her co-workers became commercial sex workers because of the support of their superior.

This was reinforced by the interview with a child commercial sex worker, who revealed that the relationship between pimps with herself as a prostitute, is like a mother and a child. Reprimand from her pimp thinks just like the direction that aims to improve the quality of her as a prostitute, who honestly admit mistakes and fix them. This is exactly what makes her forget her dream when she attends school. As Mr put it:

\begin{abstract}
"Previously, she had aspirations to work in an office, at least she has a work in a bank, but because it's too hard to eat, so she had to keep her desire to easel in an office employee." (Interview Results on November 5, 2015).
\end{abstract}

From the results of these interviews indicate that the relationship - social relationships that lead to social interaction both on individualsindividuals or groups in a space, where it can occur when there is a need and there are giving and nurturing. For example, in prostitution, activities known as pimps are very important and even absolute, pimps are defined as people (men or women) whose livelihoods are either sideline or fully provide, or participate in, finance, rent, lead and organize premises for the practice of prostitution, by conjuring or allowing 
the meeting of female prostitutes with men for intercourse.

The interview with one of the pimps in different area asserted that:

"Before she became the boss, she was a subordinate like victims. So, to make them feel at home for work, it is sufficient to make them comfortable. Child sex workers who accept sufficient lodging, food, and money experience pleasure." (10 November 2015).

The next interviews with victims of child sex tourism who works in a massage parlor asserted:

"In general, they are no longer going to school, and some have graduated from junior high school, high school dropouts have even street children who never attended school, having needs for residence and family. At pimp, they get a new family with a place to stay, and of course, accommodating them is considered their parent and vice versa." (17 November 2015).

The next interviews with a child commercial sex worker who claimed to be invited to stay at $\mathrm{M}^{\prime}$ home are as follows:

"The child in hesitant voice said the pimp appointed herself as her daughter. The pimp cares for her since she is young and provides a decent life, which cannot be obtained by both biological parents. Pimp gave her a viable place to stay, even reply to it on condition that she has to work. The work she is doing now is hard to let go, because he has a great debt to the pimp." (20 November 2015).

As she has been described above that the relationship is a pimp and victims of CSEC relationship in which there is an exchange. This is illustrated in the prostitution business relationship, between pimps and commercial sex workers Son. In the division of labor, a pimp is someone who led or governs the Child Commercial Sexual Workers in carrying out their work. In terms of working, a pimp has no authority or power over the Child Commercial Sexual Workers themselves. The relationship was occurring without any written, formal agreement or tie. The relationship between the two is based on emotion and both parties. The Child Commercial Sexual Workers will benefit or have her own right when she did her job, pimp itself will gain an advantage over its services as an intermediary between the Child Commercial Sexual Workers and its customers, the pimp itself has the right to determine the rates of the Child Commercial Sexual Workers. The relationship between pimp and the Child Commercial Sexual Workers is generally, due to the intent and purpose of each of the parties, not least because of economic necessity. Their status as first bosses are ordinary people who want to meet their daily needs, and vice versa their status as the Child Commercial Sexual Workers are initially only female job seekers, there are indeed want that, but there are also who are trapped in economic competition.

Here's the interview with a pimp who says as follows:

"As a pimp, she has duties to find customers and arranging the work of these prostitutes, as well as the owner of the place. There are also customers who themselves call for search the Child Commercial Sexual Workers. Mrs. RM also provides space and facilities for the Child Commercial Sexual Workers in making money, sometimes also provides protection to the Child Commercial Sexual Workers who is having a problem. Besides, the Child Commercial Sexual Workers sought is young and beautiful; certainly the most important is its discipline and are willing to follow the rules. The Child Commercial Sexual Workers employed by Mrs. RM is MR, RR, 
and ES." (Results Interview with the pimp, November 17, 2015).

The statement was reinforced by the results of an interview with one child commercial sex worker who stated that:

\begin{abstract}
"Pimps do not just set up a place to live and work, other than that; they feel safe to serve all its customers for their patronage of the pimp. Customers are sometimes in trouble with prices and orders that are not as expected. Such problems are solved by their pimp though sometimes until there is a big fight. Protection of their pimp is the one that makes them feel safe and feels very supported to do their works." (20 November, 2015).
\end{abstract}

The result of the above interview explained that this is exactly what motivates the Child Commercial Sexual Workers to make money quickly and more. Over time, they begin to work without knowing fatigue and a guilty race. From his work gained an average of 2 weeks is 2.000 .000 , or even be able to reach 2,000,000, if a lot of customers who come in there are booking. The payroll system is dependent on the number of tips and the number of bunds obtained.

Interviews also were conducted with $\mathrm{M}$ at one of the massage parlors stating that:

"As a pimp, she is a supplier of prostitutes to customers who simultaneously acts as the guardian of a crime PSK customers who come. Protection that can be done from a customer who acts criminally on his or her commercial sex worker who protects or if his customer does not work properly, this pimp will hire like a bouncer. Pimps who cannot report to the police are trying to protect the Child Commercial Sexual Workers." (November 23, 2015).
This is reinforced by the results of the interview with the Child Commercial Sexual Workers who worked on the M reveals that:
"As a prostitute, she receives the full facilities by a pimp, either morally and materially. The working relationship that exists between her as a prostitute and a pimp is a relationship that is tied to one another. She needs a pimp and vice versa, or it can be said between the two have mutualism symbiosis." (27 November, 2015).

Interviews with one of the pimps around the entertainment world are cafes that reinforce previous statements, that pimps can also play a role in protecting CSWs from service users who do insolence. But not always such a role can be acted by a pimp, because there is little the Child Commercial Sexual Workers become victims of violence in the hidden business fields.

Although, Pimps and victims of CSEC is an unequal relationship, but with a lack of trust and familiarity make these relationships remain stable. However, both the boss and the Child Commercial Sexual Workers have the principles of mutual profitable. As long as both parties still feel the benefits that will be obtained in the relationship, both pimp and the child commercial sexual workers will keep the relationship. But on the contrary, if one party has felt the absence of benefits that can be obtained, at least in the short term or already feel the loss of the other party, then it is also held termination of the relationship, either by mutual agreement or not.

Based on some of the above statements, agreements can be strengthened with the statement obtained from the results of interviews of people who are around the location of prostitution occurs as follows:

"The pimps and prostitutes behaved properly in their locations; they interact with the citizen well. Even if one of the prostitutes is ill, the pimp also intervened to help the 
treatment and care the prostitute. Likewise, with the prostitutes, they look obedient to the pimp."

Those statements are supported by the results of the interview of one of the residents around the site of prostitution which states that:

"The relationship between the child commercial sexual workers or therapists, health aspects are also very concerned by Mr. In as a pimp in this connection. However, slightly different from that done by the mother RM when a therapist was severely ill, Mr. just give money as a concern for the cost of the hospital, while Mrs. RM provides money and also deliver therapist to the Hospital." (Results from the Interviews with residents, 5 December 2015).

Based on the results of the interviews, it was clear that even when the pimp and the Child Commercial Sexual Workers involved in an economic relationship, but a feeling has a role to play. They are forgiving each other or feel stupid for violations or mistakes made by others throughout those actions are not result in total destruction of business.

The results of the interviews with one pimp in a cafe asserted that:

"In this relationship, the boss (pimp) utilizes its resources in the form of a place, to provide jobs for those who need and want to cooperate and are willing to work. Of course, as the pimp, she stressed his ultimate goal on economic advantage because it is the nature of its business is for profit as much as possible in his capacity as an employer or patron." (Results Interview with the pimp, December 10th, 2015).

The results of the interviews with one of Child Commercial Sexual Workers asserted that:
"As with her, as prostitutes, they use their bodies to provide services in the form of desire satisfaction of men masher for profit, in accordance with their primary purpose is to take economic advantages of selling her body." (Results of Interviews with the Child Commercial Sexual Workers, December 12, 2015).

This is reinforced by pimps interviewed by researcher stating that:

\begin{abstract}
"The relationship between her as boss and the Child Commercial Sexual Workers is based on the consideration of trust and honesty. The Child Commercial Sexual Workers who are diligent and earnest in their work usually do well. The process of the relationship between her and the Child Commercial Sexual Workers is varying, depending on the parties who are establishing the relationship itself." (Results of Interviews with the Child Commercial Sexual Workers, December 15, 2015).
\end{abstract}

Based on the results of the interview, it is evident the relationship between boss and the Child Commercial Sexual Workers is established after any unwritten work agreement, an agreement in which the Child Commercial Sexual Workers bind themselves to work for salaries of bosses. The three principles underlying the relationship between boss and prostitutes are mutual interest, mutual respect, and mutual trust.

Those principles are kept on prevalent even without any written agreement as a cooperative relationship. Factors underlying the relationship between the boss and the Child Commercial Sexual Workers are attitudes of a boss in the activities to discipline the Child Commercial Sexual Workers as workers who actually perform the job well. The rules and regulations that have been made by the boss must be obeyed by the Child Commercial 
Sexual Workers. These provisions are more inclined to say the necessity in work that should not be violated by the Child Commercial Sexual Workers. If the provision is violated, it will be bad.

Based on the interview at one of the cafes pimp as follows:

"As a boss, she has duties to find customers for the prostitutes to be booked, as well as the owner of the premises. There are also customers who are naturally called to look for the Child Commercial Sexual Workers. Mrs. TN also provides a place and means for the PL in making money. Sometimes, it also provides protection to the OT who is having problems. In addition, the Child Commercial Sexual Workers sought is young and beautiful, certainly the most important is its discipline and are willing to follow the rules." (Results of Interviews with Pimps, 17 December, 2016).

In a relationship full of intimacy between the boss and the Child, Commercial Sexual Workers seems as if they created a family atmosphere. As an informant put it:

"Pimp was considered a parent, she always provides direction in order to still be able to work well and produce a lot of money, so if given the direction we strive to obey it because it is like second parent." (Results of Interviews with the Child Commercial Sexual Workers, 20 December, 2015).

Based on the statement of the informant, we get an idea that the satisfaction of work that motivated profits between boss and child commercial sexual exploitation can generate a lot of money and the Child Commercial Sexual Workers also get a large number of salaries, it is sustainable so as to make the victim hard to avoid and withdraw from the environment (manipulation of consciousness).

\section{Efforts to Tackle Child Commercial Sexual Exploitation Victims}

Some paradigm in the theory of public policy implementation by Hogwood and Gunn (1991) will serve as the framework in dissecting the extent of the success of the efforts made by the Local Government Manado North Sulawesi in tackling child victims of commercial sexual exploitation. The paradigm of which is as follows:

1. The integration of required resources, either human resources or natural resources.

As it has been explained previously that the various regulations and programs have been initiated and organized by the local government in an effort to tackle a wide range of violence against women and children in Manado City, moved by the government policy contained in the Mayor Decree Number 51 the year 2009 on the Establishment of P2TP2A Board of Manado, North Sulawesi Province.

Integrated Services Center for Women and Children as (P2TP2A) an institution formed by the Local Government Manado North Sulawesi province has a role in the handling of victims of violence against women and children, and one form of violence is sexual abuse of a child victim.

Some of the programs organized by the Integrated Service Center for Women and Children as (P2TP2A) to provide treatment to the victims of child sexual abuse include:

a. Provide services for the victims child and parents

b. Provide guidance and counseling for the victims

c. Provide advocacy and assistance for victims ranging from investigations to cases of trial

d. Rehabilitate the health and rehabilitation of the social to the victims children and women

e. Repatriate and integrate the victims to the families and surrounding communities

f. Organize cooperation, communication 
and coordination with relevant parties including the North Sulawesi Provincial Police and the Police Resort Manado, Department / institution that cares about the problems of women and children.

The results showed that the Integrated Women and Children Empowerment Center (P2TP2A) in Manado City is carrying out its role full of various obstacles, which are limited allocation of budget and limited human resources of skilled and qualified owned by Integrated Women and Children Empowerment Center (P2TP2A) in Manado City in making the handling of child victims of sexual violence. One cause is the lack of concern for the impact to the commitment that is lower than the legislative and executive branches of Manado on the issues of exploitation of children and women in Manado City, North Sulawesi Province.

2. The level of understanding and agreement on the objectives to be achieved

As it was explained earlier, one of the roles to play by the Integrated Women and Children Empowerment Center (P2TP2A) in Manado City, North Sulawesi Province, is to deliver advocacy and assistance to victims, ranging from investigation to hearing in court. However, the reality shows that the responsibility is still qualified with various obstacles.

The results showed that of the cases of victims of commercial sexual exploitation of children is handled by P2TP2A Manado, was incomplete and not processed legally up to the level of the court. Some of the reasons include the two sides both perpetrators and victims and families, agreed to settle cases of diversion (settlement amicably), limited evidence of the victim and the family is not willing to be presented as a witness in the trial.

In addition to these constraints, the results showed that although the case has been processed legally, but still constrained to court cases of the case. Some of the obstacles which are up to the present moment have not established an agreed understanding between the police with the Judges and Prosecutors in the case of termination of cases victims of commercial sexual exploitation of children. Some indications include the docket is often back and forth from the Prosecutor to the police, the right to restitution for victims until now there has been bias are met, and if the case is prosecuted but the actors only get penalty sanctions are mild and often resolved by peaceful means.

Conditions mentioned above, according to the researchers do not deterrent for the perpetrators of the crime, the unwillingness of the victims and families reports the case because other than to be traumatized, the victim was not on his side as it should be.

\section{Perfect communication and coordination}

As earlier stated, in addition to establish Integrated Women and Children Empowerment Center (P2TP2A) in Manado City, North Sulawesi Province, in an effort to manage the victims of violence against women and children, the Local Government of Manado City has formed the Action Committee for the Elimination of Forms of Worker Worst for Kids in Manado City which was established by Mayor Decree No. 28 Year 2010.

The action committee as a coordinating body comprising representatives from local governments, government agencies, law enforcement officials, practitioners and academics, NGOs, and other relevant parties concerned with the problems of women and children in the city of Manado North Sulawesi.

The results showed that the action committees in carrying out their duties and responsibilities effectively, and still have not qualified with various obstacles. Some indications show that the membership action committee has very limited program related to the prevention and treatment of victims of commercial sexual exploitation of children, the data of victims of complaints and handling of very low compared to the number of actual cases and is often heard in various media 
(Under Estimated), and their tendency to organize action committees that are operating a basic tasks and functions work program or in accordance with internal planning, and yet the establishment of perfect communication and coordination between the committees of action to eliminate the worst forms of work for children in Manado City, North Sulawesi Province.

\section{Conclusion}

Based on the results of the study, it can be concluded that first, tourism-based economic development has negative impact on the children living in the tourism area of Manado City, in which those children are confronted with the perpetrators of child sex offenses, as the booming tourism provide access for the rich tourists to visit locations in which children and poor families are located. Second, managers of the entertainment world have important contribution to the child commercial sexual exploitation, as the child exploitation is not implemented by individuals, but by good support of the owners of cafes, bars, hotels, massage and where they usually operate, as well as direct assistance from the pimp who act as caregivers and guidance for Child Commercial Sex Workers to get customers. Third, efforts to tackle the child commercial sexual exploitation victims in Manado City, North Sulawesi Province, has not been effective because:

a. Limited allocation of budgets and skilled human resources, and the quality possessed by the Integrated Women and Children Empowerment Center (P2TP2A) in Manado City as an institution authorized by Local Government of Manado City in handling victims of child sexual violence.

b. The lack of close understanding between police, judges and public prosecutors as legal apparatus, supervision, and protection of victims in cases of the termination of child commercial sexual exploitation victims in Manado City, North Sulawesi Province.

c. The action committee in carrying out their duties and responsibilities has not been effective and still full of various obstacles. Some indications show that the membership action committee has very limited program related to the prevention and treatment of victims of commercial sexual exploitation of children, the data of victims of complaints and handling of very low compared to the number of actual cases, and is often heard in various media (Under Estimated); their tendency to organize action committees operating a basic tasks and functions program or fit departmental internal planning, as well as the perfect communication and coordination between the action committees have not been established to eliminate the worst forms of work for children in Manado City, North Sulawesi Province.

\section{References}

Hogwood, B. W., \& Gunn, L. A. (1991). Policy analysis for the real world. Oxford: ELBS with Oxford University Press.

Child Wise Tourism Report. (2007). Asean child sex tourism review. Jakarta: Child Wise Tourism Report.

Cresswell, J., W. (2013). Research design:qualitative, quantitative, and mixed methods approach. Thousand Oaks: SAGE Publications.

DeLeon, P. \& Martell, C., R. (1998). The Policy Sciences: Past, Present, and Future. In Peters, B. G. \& Pierre, J. (Eds.), Handbook of Public Policy, (pp. 31-48). London: SAGE Publication.

Dwijowiyoto, R., N. (2003). Kebijakan publik, formulasi, implementasi, dan evaluasi. Jakarta: PT. Elex Media Komputindo.

Nuraeny, H. (2011). Tindak pidana perdagangan orang: kebijakan hokum pidana dan pencegahannya. Jakarta, Indonesia: Sinar Grafika.

Suyanto, B. (2010). Masalah sosial anak. Jakarta: Kencana.

Surjono, G., \& Ahyar, S. (2009). Pengkajian penanggulangan permasalahan sosial perdagangan (trafficking) anak dan perempuan. Yogyakarta: B2P3KS Press. 